\title{
Short communication: a survey of grass- clover ley management and creation of a near infra-red reflectance spectroscopy equation to predict clover concentration
}

Article

Supplemental Material

Creative Commons: Attribution-Noncommercial-No Derivative Works 4.0

Thomson, A. L., Humphries, D. J., Archer, J. E., Grant, N. W. and Reynolds, C. K. (2018) Short communication: a survey of grass-clover ley management and creation of a near infra-red reflectance spectroscopy equation to predict clover concentration. Animal Feed Science and Technology, 245. pp. 48-53. ISSN 0377-8401 doi:

https://doi.org/10.1016/j.anifeedsci.2018.09.003 Available at https://centaur.reading.ac.uk/79139/

It is advisable to refer to the publisher's version if you intend to cite from the work. See Guidance on citing.

To link to this article DOI: http://dx.doi.org/10.1016/j.anifeedsci.2018.09.003

Publisher: Elsevier

All outputs in CentAUR are protected by Intellectual Property Rights law, including copyright law. Copyright and IPR is retained by the creators or other copyright holders. Terms and conditions for use of this material are defined in the End User Agreement. 


\section{www.reading.ac.uk/centaur}

\section{CentAUR}

Central Archive at the University of Reading

Reading's research outputs online 
Supplementary Table $1 \mathrm{~A}$ list of questions that were asked within a questionnaire given to farmers that offered a grass-clover silage sample for inclusion in a dataset to test and improve Near Infra-red Reflectance Spectroscopy equations in the UK. Questions related to agronomy and ensiling practices used on the sward from which the sample originated.

\begin{tabular}{|c|c|c|}
\hline $\begin{array}{l}\text { Question } \\
\text { number }\end{array}$ & Question & $\begin{array}{l}\text { Number of } \\
\text { respondents }\end{array}$ \\
\hline 1 & Establishment date & 59 \\
\hline 2 & Establishment method & 59 \\
\hline 3 & Age of pasture & 61 \\
\hline 4 & Grass varieties sown (and rate) & $49(44)$ \\
\hline 5 & Clover varieties sown (and rate) & $46(43)$ \\
\hline 6 & Applications prior to cutting (including FYM/slurry/chemicals) & 45 \\
\hline 7 & Cutting date & 62 \\
\hline 8 & Silage cut (i.e. $1^{\text {st }}, 2^{\text {nd }}$ ) & 59 \\
\hline 9 & Estimated clover percentage in sward & 55 \\
\hline 10 & Weed problems & 48 \\
\hline 11 & Time wilted (in hours) & 60 \\
\hline 12 & Chop length (in cm, where applicable) & 33 \\
\hline 13 & Clamp type (where applicable) & 34 \\
\hline 14 & Bale wrap layers (where applicable) & 43 \\
\hline 15 & Dry matter of silage & 26 \\
\hline 16 & Additives used & 30 \\
\hline 17 & Silage analysis (if known) & \\
\hline $17(a)$ & Metabolisable energy & 18 \\
\hline $17(b)$ & Protein & 19 \\
\hline $17(c)$ & Fibre & 15 \\
\hline $17(d)$ & Ash & 17 \\
\hline $17(\mathrm{e})$ & D value & 17 \\
\hline
\end{tabular}

